\title{
Ján Botík \\ An Ethnic History of Slovakia: Multi-ethnicity, Minorities, and Migrations
}

DOI: 10.31577/EtnoRozpra.2021.28.2.10

\section{Michal Uhrin}

\section{Acknowledgement}

Vydanie príspevku bolo podporené grantom VEGA č. 1/0194/20 Morálne naratívy o náboženských a etnických skupinách vo vyučovaní vybraných predmetov na základných školách.

\section{Kontakt / Contact}

Mgr. Michal Uhrin, PhD., Filozofická fakulta Univerzity Komenského v Bratislave, Gondova 2, 81102 Bratislava, Slovenská republika, e-mail: michal.uhrin@uniba.sk

ORCID iD https://orcid.org/0000-0002-8062-5785

\section{Ako citovat' / How to cite}

Uhrin, M. (2021). Ján Botík. An Ethnic History of Slovakia: Multi-ethnicity, Minorities, and Migrations. Etnologické rozpravy, 28(2), 91-93. https://doi.org/10.31577/

EtnoRozpra.2021.28.2.10

Ján Botík: An Ethnic History of Slovakia: Multi-ethnicity, Minorities, and Migrations. Bratislava: Stimul, 2021, 341 s.

Kniha An Ethnic History of Slovakia: Multi-ethnicity, Minorities, and Migrations (Botík, 2021) predstavuje významnú publikáciu na poli etnológie a histórie. Autor publikácie, profesor Ján Botík, je slovenský etnológ a muzeológ, emeritný univerzitný profesor, člen mnohých vedeckých spoločností a redakčných rád prestížnych časopisov. Absolvoval množstvo výskumných pobytov v Mad’arsku, Rumunsku, Srbsku, Bulharsku, Argentíne, USA či Kanade (bližšie pozri Maráky, Hlôšková a kol., 2018; Uhrin, 2019).

K jeho odborným záujmom patrí problematika rodiny a príbuzenstva, l'udovej architektúry a bývania. Botíkov dlhodobý akademický záujem sa však sústred'uje najmä na problematiku etnicity, etnickej histórie Slovenska, Slovákov žijúcich v zahraničí, etnických menšín žijúcich na Slovensku, na teóriu etnicity a migračné štúdiá (Botík, 1999, 2001, 2002, 
2007, 2011, 2016). Dlhodobý záujem o problematiku etnicity v etnologických a historických kontextoch sa odráža aj v publikácii An Ethnic History of Slovakia: Multi-ethnicity, Minorities, and Migrations (Botík, 2021).

Publikácia je prekladom slovenskej verzie knihy Etnická história Slovenska: k problematike etnicity, etnickej identity, multietnického Slovenska a zahraničných Slovákov (Botík, 2007). Anglický text knihy je takmer obsahovo identický so slovenskou verziou. Táto skutočnost' však v žiadnom prípade neuberá na význame a spoločenskej i akademickej hodnote prekladu. Domnievam sa, že je to práve naopak. Anglickou verziou kniha dostáva príležitost' preniknút do nového jazykového prostredia a začína žit istým spôsobom "nový život".

Z obsahového hl'adiska okrem úvodu, ktorý podáva prvý vstup do problematiky, a záveru, ktorý ponúka výstižné zhrnutie, je kniha členená na štyri rozsiahle tematické kapitoly: Multi-ethnic Slovakia and minority studies; An ethnic understanding of Slovakia; Multi-ethnic Slovakia and its variety of cultural forms; Slovak expatriates. Zámerom knihy je prezentovat' etnickú históriu Slovákov a d’alších etník žijúcich na území Slovenska. K nim patria Mad’ari, Nemci, Židia, Rusíni, Ukrajinci, Rómovia, Chorváti, Srbi, Bulhari a Česi. Táto kniha však zahŕňa informácie aj o skupinách Slovákov, ktorí hromadne emigrovali do mnohých európskych a zámorských krajín a sleduje procesy ovplyvňujúce premeny ich identity. Botík sa zameriava na historické, sociálne a kultúrne aspekty etnických procesov. Inherentnou súčastou kapitol sú ilustrácie a mapy, ktoré pomáhajú čitatel’om získat’ ucelený obraz o problematike.

Na príprave anglickej verzie knihy sa redaktorsky podielala profesorka etnológie Marta Botiková z Katedry etnológie a muzeológie Filozofickej fakulty Univerzity Komenského v Bratislave, ktorá sa taktiež dlhodobo venuje otázkam etnicity a Slovákov žijúcich v zahraničí. Preklad zabezpečil Dr. John Peter Butler Barrer z Katedry anglistiky a amerikanistiky Filozofickej fakulty Univerzity Komenského v Bratislave. Preklad vznikol v kolektíve vyznačujúcom sa vysokou mierou erudície. Preklad podporil z verejných zdrojov Fond pre podporu umenia.

Anglická verzia knihy bola oficiálne uvedená 21. júna 2021. Z dôvodu aktuálnej pandemickej situácie a nariadení Vlády Slovenskej republiky, ako aj Úradu verejného zdravotníctva sa uvedenie konalo online. Uvedenie knihy zorganizovala Katedra etnológie a muzeológie Filozofickej fakulty Univerzity Komenského v Bratislave. Aj napriek tomu, že nebolo možné diskutovat’ s autorom, redaktorkou a prekladatel'om tvárou v tvár, sa v digitálnych vodách rozprúdila podnetná diskusia. Diskutujúci otvorili viaceré otázky, tykajúce sa nielen prekladu či obsahu publikácie, ale aj problematiky online publikácií a verejných licenčných zmlúv.

Za prínosné považujem, že kniha vyšla ako elektronická publikácia. Pandémia COVID-19 viacerým vzdelávacím inštitúciám ukázala, aké je dôležité disponovat' aj elektronickými zdrojmi a študijnými materiálmi. Na uvedení knihy sa zúčastnila aj Mgr. Jana llavská, ako zástupkyňa Akademickej knižnice Univerzity Komenského, ktorá zodpovedala viaceré otázky, týkajúce sa elektronických publikácií. Tie sa vztahovali najmä k výhodám a nevýhodám publikácii vychádzajúcich výlučne online.

Kniha svojou povahou nie je primárne vysokoškolskou učebnicou. Šírkou obsiahnutej problematiky a híbkou, do akej ju profesor Botík analyzuje, presahuje rámec učebníc 
- ide o vedeckú monografiu. Vd’aka svojej šírke a híbke záberu a analytickému postupu však predstavuje zároveň vynikajúci učebný text nielen pre študentov humanitných a sociálnych vied, ale napríklad aj pre študentov humánnej či kultúrnej geografie. Kniha môže byt taktiež využitá ako pedagogická a didaktická pomôcka vo vyučovacom procese pre zahraničných študentov, študujúcich na slovenských univerzitách či dokonca na stredných školách. Spoločenská a vedecká hodnota publikácie je širokospektrálna.

Porozumenie historických vztahov a etnologických kontextov spolužitia príslušníkov rôznych etník na území Slovenska môže pomôct’ prekonávat' bariéry vznikajúce z nepochopenia inakostí a odlišností. Publikácia je tak významná nielen pre študentov, ale aj pre všetkých záujemcov o etnickú históriu Slovenska.

\section{Referencie}

Botík, J. (1999). Tam zložili aj svoje kosti: Kultúrnohistorické hodnoty náhrobných pomnikov zahraničných Slovákov. Bratislava: Lúč.

Botík, J. (2001). Slovenskí Chorváti: Etnokultúrny vývin z pohladu spoločenskovedných poznatkov. Bratislava: Lúč.

Botík, J. (2002). Slováci v argentínskom Chacu: Historický a etnokultúrny vývin pestovatelov bavlny. Bratislava: Lúč.

Botík, J. (2007). Etnická história Slovenska: k problematike etnicity, etnickej identity, multietnického Slovenska a zahraničných Slovákov. Bratislava: Lúč.

Botík, J. (2011). Dolnozemskí Slováci. Tri storočia vystahovaleckých osudov, spôsobu života a identity Slovákov v Mad’arsku, Rumunsku, Srbsku a Bulharsku. Nadlak: Vydavatel'stvo Ivan Krasko.

Botík, J. (2016). Slováci vo Vojvodine: premeny svojbytnosti enklávneho spoločenstva. Nový Sad: Ústav pre kultúru Slovákov vo Vojvodine.

Botík, J. (2021). An Ethnic History of Slovakia: Multi-ethnicity, Minorities, and Migrations. Bratislava: Stimul. http://stella.uniba.sk/texty/FIF_JB_Ethnic_history_of_Slovakia.pdf

Maráky, P., Hlôšková, H., Botíková, M. (Eds.). (2018). Cesty Jána Botíka: zborník venovaný životným cestám etnografa prof. PhDr. Jána Botíka, DrSc. pri priležitosti životného jubilea. Bratislava: Lúč.

Uhrin, M. (2019). A chapter from history of Slovak ethnology - the analysis of work and life of Ján Botík. Ethnologia Slovaca et Slavica, 40, 115-123. http://alis.uniba.sk/storage/ uk/fif/acta/EthnologiaSetS-40.pdf 